K A N D A I

\begin{tabular}{|l|l|l|}
\hline Volume 15 & No. 2, November 2019 & Halaman 249-260 \\
\hline
\end{tabular}

\title{
MEDAN MAKNA AKTIVITAS TANGAN "MENYAKITI" \\ DALAM VERBA BAHASA SUNDA \\ (The Meaning Field of Hand "Hurting" Activity in Sundanese Verb)
}

\author{
Emma Maemunah \\ Balai Bahasa Jawa Tengah \\ Jalan Elang Raya No. 1, Mangunharjo, Tembalang \\ Semarang 50272, Indonesia \\ Pos-el: emma.maemunah@kemdikbud.go.id
}

(Diterima 1 April 2019; Direvisi 29 Agustus 2019; Disetujui 29 Agustus 2019)

\begin{abstract}
Verbs of hand activities of "hurting" in Sundanese have many lexemes. Although the meaning of the lexemes of "hurting" in general is hitting, the semantic function of the lexemes differs depending on the component of meaning they have. This study aims to describe the component meaning of the hand activity of "hurting" in Sundanese and explain the semantic function of those hand activities. Data are obtained from written sources, namely the Dictionary of Sundanese Language. The data of this qualitative research with descriptive method is a list of vocabulary (cognate) based on the meaning of "hurting" in Sundanese. Data are analyzed by paraphrasing and classifying techniques. The analyses result shows that the hand activities of "hurting" in Sundanese could be divided into two groups, based on the components of generic meanings and the tools used and into three subgroups, namely hand activities of hurting the body, hand activities of hurting the head and its parts, and hand activities of hurting the neck. Tha hand activities of hurting the body as much as 24 lexemes consist of 14 lexemes of activity using a tool and 10 lexemes of activity without using tools. The activities of hurting the head and its parts are 17 lexemes which consist of 2 lexemes are using tools and 15 lexemes are without using tools. The lexeme of hand activites hurting the neck consists of 1 lexeme using a tool and 2 lexeme without using tools.
\end{abstract}

Keywords: Sundanese, "hurting" hand activity, meaning, semantic function

\begin{abstract}
Abstrak
Verba aktivitas tangan "menyakiti" dalam bahasa Sunda memiliki banyak leksem. Meskipun makna leksem aktivitas tangan "menyakiti" pada umumnya adalah memukul, fungsi semantis leksem-leksem tersebut berbeda bergantung pada komponen makna yang dimilikinya. Penelitian ini bertujuan mendeskripsikan komponen makna verba aktivitas tangan "menyakiti" dalam bahasa Sunda dan menjelaskan fungsi semantis medan makna verba aktivitas tangan tersebut. Penelitian ini berjenis kualitatif dengan metode deskriptif. Data diperoleh dari sumber tertulis, yaitu Kamus Bahasa Sunda. Data berupa daftar kosakata (kognat) yang bermedan makna "menyakiti" dalam bahasa Sunda. Data dianalisis dengan teknik parafrase dan pengklasifikasian. Hasil penelitian menunjukkan bahwa aktivitas tangan "menyakiti" dalam bahasa Sunda dapat dibagi ke dalam dua kelompok, yakni berdasarkan komponen makna generik dan alat yang digunakan dan tiga subkelompok, yaitu aktivitas tangan menyakiti badan, aktivitas menyakiti kepala dan bagiannya, dan aktivitas menyakiti leher. Aktivitas tangan menyakiti badan sebanyak 24 leksem terdiri atas 14 leksem aktivitas menggunakan alat dan 10 leksem aktivitas menyakiti badan tanpa menggunakan alat. Aktivitas menyakiti kepala dan bagiannya sebanyak 17 leksem terdiri atas 2 leksem aktivitas menyakiti kepala dan bagiannya menggunakan alat dan 15 leksem aktivitas tangan "menyakiti" kepala dan bagiannya tanpa menggunakan
\end{abstract}


alat. Leksem aktivitas tangan menyakiti leher terdiri atas 1 leksem aktivitas menyakiti leher menggunakan alat dan 2 leksem aktivitas menyakiti leher tanpa menggunakan alat.

Kata-kata kunci: bahasa Sunda, aktivitas tangan "menyakiti", makna, fungsi semantis

DOI: $10.26499 / j k . v 15 i 1.1239$

How to cite: Maemunah, M. (2019). Medan makna aktivitas tangan menyakiti dalam verba bahasa Sunda. Kandai, 15(2), 249-260(DOI: 10.26499/jk.v15i1.1239)

\section{PENDAHULUAN}

Inventarisasi kosakata bahasa daerah sudah banyak dilakukan, bahkan kosakata-kosakata tersebut turut memperkaya lema dalam Kamus Besar Bahasa Indonesia (KBBI). Sebagai contoh, kata bahasa Sunda ngabuburit 'menunggu azan magrib menjelang berbuka puasa pada waktu bulan Ramadan' sudah masuk ke dalam KBBI. Kata ngabuburit berasal dari kata dasar burit 'waktu petang' yang umumnya ditandai dengan bunyi tabuhan beduk dari masjid atau surau. Kemudian, kata bahasa Jawa angsu 'ambil air; angkut air (dari sumur dan sebagainya)' pun sudah ada di dalam KBBI. Selain bahasa Sunda dan Jawa, kosakata bahasa daerah di Indonesia yang lain pun banyak yang sudah masuk ke dalam KBBI, seperti kata bahasa Bali druwe 'tanah (garapan dan sebagainya) yang dimiliki oleh raja', kata bahasa Aceh barah 'bengkak yang mengandung nanah (karena infeksi; bisul)', dan kata bahasa Batak dolok 'gunung'.

Peran dan fungsi bahasa daerah tidak hanya digunakan sebagai bahasa percakapan masyarakat tuturnya. Bahasa daerah juga digunakan dalam penyelenggaraan upacara adat dan kesenian tradisional. Oleh karena itu, kelestarian bahasa daerah berhubungan erat dengan kelestarian budayanya. Berbagai upaya dilakukan untuk menjaga kelestarian bahasa dan budaya daerah, seperti mengajarkan bahasa daerah di sekolah sebagai muatan lokal. Beberapa instansi pemerintah yang terkait dengan bidang bahasa dan budaya juga melakukan upaya-upaya, seperti menginventarisasi budaya dan kosakata bahasa daerah, melakukan penelitian/pengkajian budaya dan bahasa daerah, serta mengadakan lomba-lomba yang berkaitan dengan bahasa dan budaya daerah.

Setiap bahasa daerah memiliki proses pembentukan kata yang unik. Hal tersebut terlihat pada proses pembentukan verba aktivitas tangan dalam bahasa Sunda. Pembentukan verba dapat berdasarkan atas bagian tangan yang bergerak, arah pergerakan tangan, sasaran gerakan tangan, dan benda/alat yang dipegang oleh tangan. Contoh verba yang terbentuk berdasarkan bagian tangan yang bergerak adalah siku [siku] 'sendi tangan antara lengan atas dan lengan bawah'. menjadi nyiku 'menyiku'. Kata jiwir [jiwir] 'jewer' menjadi ngajiwir 'menjewer' merupakan verba yang terbentuk berdasarkan sasaran gerakan tangan, yaitu telinga' dan alat yang digunakan, yaitu keureut [köröt] menjadi ngeureut [nöröt] 'mengerat dengan pisau'.

Bahasa Sunda merupakan bahasa daerah di Jawa Barat yang memiliki jumlah penutur sangat banyak. Seperti halnya bahasa daerah yang lain di Indonesia, bahasa Sunda pun digunakan dalam percakapan penuturnya, dalam upacara-upacara budaya, dan dalam adat istiadat masyarakat Sunda. Hal tersebut sejalan dengan pernyataan Darheni bahwa bahasa juga merupakan produk perkembangan sebuah budaya yang memiliki kekuatan dan keunikan yang diwujudkan dalam leksikon. Beberapa 
leksikon dalam bahasa Sunda, misalnya leksikon aktivitas yang berhubungan dengan indera mata yang terdapat dalam khazanah kosakata bahasa Sunda. Perkembangan zaman dan situasi sosial masyarakat di Jawa Barat berdampak pada perkembangan leksikon bahasa Sunda (Darheni, 2010). Jadi, bahasa dan budaya daerah merupakan dua hal penting karena budaya dan bahasa daerah merupakan identitas dan jatidiri diri masyarakatnya.

Pertanyaannya, apakah semua penutur bahasa Sunda saat ini masih menggunakan semua kosakata aktivitas tangan menyakiti? Herdiana, (2011) menyebutkan bahwa pengguna bahasa Sunda dalam pergaulan generasi muda saat ini jumlahnya sangat sedikit. Akibatnya, kelestarian bahasa Sunda terancam punah. Hasil penelitian Balai Bahasa Bandung yang dilakukan selama dua tahun (2008-2009) menunjukkan bahwa jumlah keluarga yang menggunakan bahasa Sunda dalam pergaulan sehari-hari tinggal 43 persen.

Oleh karena itu, penulis merumuskan permasalahan penelitian ini menjadi bagaimanakah komponen makna verba aktivitas tangan "menyakiti" dalam bahasa Sunda dan bagaimana pula fungsi semantis medan makna aktivitas tangan "menyakiti" bahasa Sunda? Berdasarkan rumusan masalah tersebut tujuan penelitian ini adalah mendeskripsikan komponen makna verba aktivitas tangan "menyakiti" dalam bahasa Sunda dan menjelaskan fungsi semantis medan makna aktivitas tangan "menyakiti" bahasa Sunda.

Penelitian semantik ini dilakukan agar masyarakat mengenal bahasa daerah, menyadari pentingnya pemertahanan bahasa daerah, dan memunculkan sikap baik masyarakat terhadap bahasa daerahnya, dalam hal ini bahasa Sunda. Sikap baik masyarakat dalam menggunakan bahasa daerah akan membuat bahasa daerah kuat dan bertahan, tidak tergeser oleh bahasa lain, atau hilang tertelan zaman. Selain itu, hasil penelitian ini dapat membantu memperkaya kosakata dan menambah lema Kamus Besar Bahasa Indonesia.

Penelitian verba aktivitas tangan telah banyak dilakukan dengan objek bahasa daerah (dialek) yang berbeda. Salah satunya adalah penelitian tentang verba aktivitas tangan yang dilakukan oleh Anharuddin Hutasuhut dalam tesisnya yang berjudul "Medan Makna Aktivitas Tangan dalam Bahasa Mandailing" pada tahun 2008. Anharuddin mengkaji medan makna aktivitas tangan dalam bahasa Mandailing dengan menggunakan data berupa leksem verbal yang menyatakan konsep aktivitas tangan. Konsep tersebut lazim digunakan oleh masyarakat penutur bahasa Mandailing. Penelitian semantik dengan menggunakan analisis komponen makna ini menemukan bahwa bahasa Mandailing memiliki dua puluh submedan, yaitu maniop, manjama, mambuat, mangoban, mamayakkon, mangaramban, mangalehen, manarimo, mambuka, manutup, manarik, mamisat, manghanciti, mangalala, manggulung, mamio, mangayak, mangambat, manjalang, manudu (Hutasuhut, 2008).

Penelitian aktivitas tangan yang lebih spesifik dilakukan oleh Darlisanto (2014) dengan fokus medan makna verba memukul dalam bahasa Melayu Sambas. Darlisanto mendeskripsikan medan makna verba memukul bahasa Melayu Sambas dan menemukan 39 leksem verba memukul dalam bahasa Melayu Sambas yang memiliki medan makna, komponen makna, jenis makna, dan fungsi semantis. Komponen makna verba memukul menggunakan alat adalah ambat, ampaskan, bepapas, kabbas, nampak, ngampok, ngantak, ngatcap, nukkok, nukkol, numbok, pangkong, 
pappah, rimpat, dan tutjah. Komponen makna verba memukul tanpa alat adalah begandang, belampang, benteh, betappok, ca, gaddor, gerammus, ippok, jantek, ngattek, ngattok, nyiggong, sepak, taggum, tampar, tappak, tappek, teratjang, tikkak, tonyoh, tulakkan, tumbok, dan tunjal. Komponen makna verba memukul bisa menggunakan alat dan tanpa alat diperoleh data seperti kata pappah, tappak, dan simis.

Penelitian ini berbeda dengan penelitian yang dilakukan oleh Hutasuhut dan Darlisanto. Hutasuhut membahas semua verba aktivitas tangan dan Majinur hanya membahas verba memukul, sementara penelitian ini membahas verba aktivitas tangan "menyakiti". Batasan pengertian verba aktivitas tangan "menyakiti" dalam penelitian ini adalah aktivitas tangan yang dilakukan oleh seseorang pada orang lain, baik secara sengaja maupun tidak dan aktivitas tangan tersebut menimbulkan rasa sakit. Hal tersebut dapat dilihat dari fungsi semantis dari tiap leksem aktivitas tangan menyakiti. Misalnya, verba koét [kowet] dan kerewes [kərəwəs] memiliki makna yang sama dalam bahasa Indonesia, yaitu 'cakar:mencakar'. Akan tetapi, fungsi semantis kedua kata tersebut berbeda. Verba koét [kowet] memiliki fungsi semantis menyakiti dengan mencakar bagian tubuh mana saja, seperti badan, tangan, dan kaki, sementara kerewes [kərəwəs] memiliki fungsi semantis menyakiti dengan mencakar bagian muka (wajah).

\section{LANDASAN TEORI}

Penelitian verba aktivitas tangan "menyakiti" dalam bahasa Sunda ini berhubungan dengan makna yang merupakan bagian dari penelitian semantik. Kata "menyakiti" secara denotatif memiliki makna menyebabkan rasa sakit seperti sedih, sengsara, dan sebagainya. (Saeed, 2016) mendefinisikan semantik sebagai studi tentang makna kata dan kalimat. Berbeda dengan Saeed, (Kreidler, 1998) menjelaskan bahwa semantik adalah studi sistematik makna dan semantik dalam linguistik adalah bagaimana bahasa mengorganisasi dan mengekspresikan makna. Sementara itu, Chaer menyatakan bahwa semantik adalah ilmu tentang makna dan tentang arti, yaitu salah satu dari tiga tataran analisis bahasa; fonologi, gramatika, dan semantik (Chaer, 2013).

Makna merupakan hubungan antara bahasa dengan bahasa luar yang disepakati bersama oleh pemakai bahasa sehingga dapat saling dimengerti (Aminuddin, 1998). Definisi tersebut sejalan dengan pendapat Soedjito yang menyatakan bahwa makna ialah hubungan antara bentuk bahasa dan barang (hal) yang diacunya (Soedjito, 1990).

Sebuah kata dapat dianggap berada dalam satu medan makna. dengan kata lain apabila memiliki unsur leksikal yang maknanya berhubungan. Hal itu dijelaskan oleh Kridalaksana, (2008), yaitu bahwa medan makna adalah bagian dari sistem semantik bahasa yang menggambarkan bagian dari bidang kehidupan atau realitas dalam alam semesta tertentu dan yang direalisasikan oleh seperangkat unsur leksikal yang maknanya berhubungan. Misalnya nama warna membentuk medan makna tertentu, begitu pula nama perabot rumah tangga, resep makanan dan minuman, peristilahan penerbangan, dan seterusnya.

Widdowson (1996) menyatakan bahwa analisis komponensial adalah teknik untuk mendeskripsikan hubungan suatu referen dengan memilah-milah setiap konsep menjadi komponen minimal atau ciri-ciri, seperti keadaan, 
proses, hubungan sebab akibat, hubungan relasional kelompok atau kelas, kepemilikan dimensi atau ruang, lokasi, dan arah.

Teori yang digunakan untuk menganalisis komponen makna aktivitas tangan "menyakiti" dalam bahasa Sunda adalah teori dari E. A Nida yang menyatakan bahwa satuan leksikal menyatakan kesatuan makna yang dapat diuraikan sampai pada komponen terkecilnya.

Nida (1975) menguraikan prosedur analisis komponen dalam empat teknik, yaitu penamaan, parafrase, pendefinisian dan pengklasifikasian. Proses penamaan berkaitan dengan referen atau acuannya. Parafrase merupakan deskripsi lain dari suatu leksem, misalnya paman dapat diparafrase menjadi adik laki-laki ayah atau adik laki-laki ibu. Pendefinisian merupakan bentuk lain dari parafrase, yaitu menggabungkan semua parafrase yang spesifik menjadi satu pernyataan berdasarkan komponen diagnostiknya. Pengklasifikasian adalah cara memberikan pengertian pada suatu kata dengan cara menghubungkan kata yang satu dengan kata yang lain dengan cara mengumpulkan kata-kata yang memiliki kesamaan tertentu, memisahkan katakata yang berbeda antara satu dengan lainnya, dan menentukan dasar pengelompokannya.

Leksikon adalah komponen bahasa yang memuat semua informasi tentang makna dan pemakaian kata dalam bahasa; daftar kata yang disusun seperti kamus, tetapi dengan penjelasan yang singkat dan praktis (Kridalaksana, 2008). Bahasa Sunda memiliki verba aktivitas tangan (untuk menyakiti) dan diwujudkan dalam banyak leksikon, seperti babuk, gebug, peupeuh, dan teunggeul. Makna umum setiap leksikon adalah memukul, tetapi aktivitas memukul tersebut bergantung pada proses memukulnya, seperti menggunakan alat atau tidak, bagian tangan yang digunakan untuk memukul (telapak tangan, punggung tangan, jari, mengepal, dan sebagainya), dan apa atau bagian tubuh mana yang terkena pukulan tersebut. Hal itu dapat diketahui dengan melihat fungsi semantis kata-kata tersebut.

Fungsi atau peran semantis didefinisikan sebagai hubungan antara predikat dan argumen sebagai sebuah preposisi. Preposisi adalah struktur makna klausa. Predikat, sebagai konsep semantis adalah proposisi yang menyatakan perbuatan, proses, keadaaan, kualitas, lokasi dan identitas. Argumen merupakan bagian preposisi yang mengacu pada wujud bernyawa dan tak bernyawa atau mengacu pada keniskalaan yang berhubungan dengan predikat. Predikat dinyatakan dalam bentuk verba non-verba, sedangkan argumen, yang disebut pula partisipan, dinyatakan dalam bentuk nomina atau frasa nominal yang menyertai predikat. Secara gramatikal, peran semantis dapat didefinisikan sebagai makna argumen yang ditentukan oleh struktur formal terhadap predikat (Wedhawati, 2006 dalam Malay, 2017).

\section{METODE PENELITIAN}

Penelitian medan makna aktivitas tangan "menyakiti" dalam bahasa Sunda ini berjenis kualitatif dengan metode deskriptif. Peneliti kualitatif sebagai human instrument berfungsi menetapkan fokus penelitian, memilih informan sebagai sumber data, melakukan pengumpulan data, menilai kualitas data, analisis data, menafsirkan data, dan membuat kesimpulan atas temuannya (Sugiyono, 2012). Sesuai dengan metode tersebut, penulis mengumpulkan data untuk dinilai, dianalisis, ditafsirkan, dan disimpulkan. Data penelitian ini adalah daftar kosakata (kognat) yang bermedan 
makna "menyakiti" dalam bahasa Sunda. Data diperoleh dari sumber tertulis, yaitu Kamus Bahasa Sunda. Medan makna aktivitas tangan "menyakiti" yang dianalisis mencakupi aktivitas tangan yang dilakukan oleh seseorang pada orang lain, baik secara sengaja maupun tidak dan aktivitas tangan tersebut menimbulkan rasa sakit.

Data dianalisis dengan teknik parafrase dan pengklasifikasian. Teknik parafrase dilakukan dengan memilah data berdasarkan adanya alat yang digunakan dalam melakukan aktivitas tangan "menyakiti", kemudian diuraikan menggunakan analisis komponensial. Klasifikasi data dilakukan dengan menyusun data secara terstruktur dalam kelompok sesuai masalah yang diteliti, yaitu (1) leksikon aktivitas tangan "menyakiti" dalam bahasa Sunda dan (2) fungsi semantis setiap leksikon aktivitas tangan "menyakiti" dalam bahasa Sunda.

\section{PEMBAHASAN}

Berdasarkan klasifikasi data leksem aktivitas tangan "menyakiti" dalam bahasa Sunda dibagi ke dalam dua kelompok, yaitu berdasarkan komponen makna generik dan alat yang digunakan untuk melakukan tindakan menyakiti. Kelompok aktivitas tangan "menyakiti" dalam bahasa Sunda tersebut terdiri atas tiga subkelompok, yaitu aktivitas menyakiti badan, aktivitas menyakiti kepala dan bagiannya, dan aktivitas menyakiti leher. Berikut skema pengelompokan kelompok dan subkelompok leksem aktivitas tangan menyakiti.

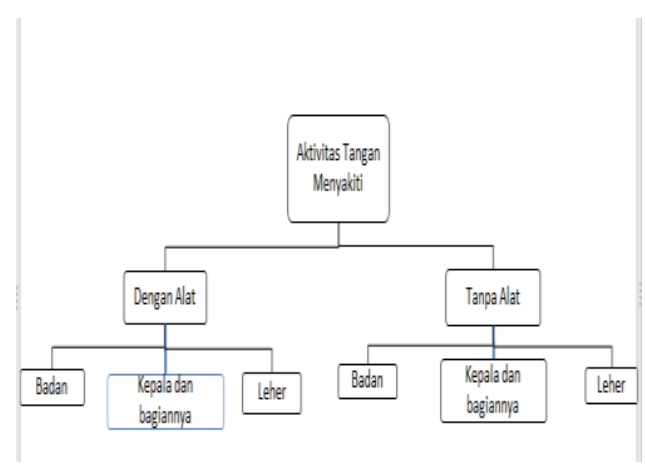

\section{Aktivitas Tangan Menyakiti Badan}

Aktivitas tangan menyakiti badan dalam bahasa Sunda ditemukan 24 leksem yang terdiri atas 14 aktivitas tangan menyakiti dengan menggunakan alat dan 10 aktivitas tangan menyakiti tanpa menggunakan alat.

Leksem aktivitas tangan "menyakiti" badan dengan menggunakan alat adalah bacok [bacok], baledog [balcdog], ceprét [cəpret], gebug [gəbug], jepret [jəpret], kadék [kadek], paléngpéng [palejpcy], pecut [pəcut], peupeuh [pöpöh], sabet [sabət], teunggeul [töngöl], tojos [tojos], dan tubles [tublos].

Leksem aktivitas tangan "menyakiti" badan tanpa menggunakan alat adalah beubeut [böböt], cakar [cakar], ciwit [ciwit], coco [coco], jotos [jotos], koét [kowet], pencét [pəncet], perekpek [parəkpek], peureup [pöröp], talikung [talikuy], tinggang [tingan], dan tonjok [tonjok]. Penjelasan leksem aktivitas tangan menyakiti badan dapat dilihat pada tabel-tabel berikut. 
Tabel 1

Aktivitas tangan menyakiti badan dengan menggunakan alat .

\begin{tabular}{|c|c|c|c|c|c|c|c|}
\hline \multirow[b]{3}{*}{ Leksem } & \multicolumn{7}{|c|}{ Komponen Makna } \\
\hline & \multicolumn{4}{|c|}{ Alat } & \multicolumn{3}{|c|}{$\begin{array}{c}\text { Posisi } \\
\text { telapak } \\
\text { tangan }\end{array}$} \\
\hline & 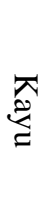 & $\begin{array}{l}\text { 芯 } \\
\stackrel{\widetilde{\Xi}}{\Xi}\end{array}$ & 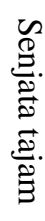 & 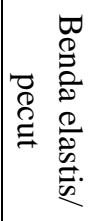 & 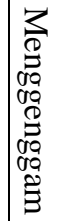 & & 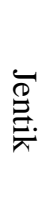 \\
\hline $\begin{array}{l}\text { babuk } \\
\text { [babuk] }\end{array}$ & + & - & + & - & + & - & - \\
\hline $\begin{array}{l}\text { gebug } \\
\text { [gəbug] }\end{array}$ & + & - & - & - & + & - & - \\
\hline $\begin{array}{l}\text { peupeuh } \\
\text { [pöpöh] }\end{array}$ & + & - & - & - & + & - & - \\
\hline $\begin{array}{l}\text { teunggeul } \\
\text { [töngöl] }\end{array}$ & + & - & - & - & + & - & - \\
\hline $\begin{array}{l}\text { bacok } \\
\text { [bacok] }\end{array}$ & - & - & + & - & + & - & - \\
\hline $\begin{array}{l}\text { kadék } \\
{[\mathrm{kad} \varepsilon \mathrm{k}]} \\
\end{array}$ & - & - & + & - & + & - & - \\
\hline sabet [sabət] & - & - & + & - & + & - & - \\
\hline $\begin{array}{l}\text { baledog } \\
\text { [baledog] }\end{array}$ & & + & - & - & + & - & - \\
\hline $\begin{array}{l}\text { paréngpéng } \\
\text { [parenpsy] }\end{array}$ & + & + & - & - & + & - & - \\
\hline $\begin{array}{l}\text { ceprét } \\
\text { [copret] }\end{array}$ & - & - & - & + & - & - & + \\
\hline pecut [pəcut] & - & - & - & + & + & - & - \\
\hline jepret [jəpret] & - & - & - & + & - & - & + \\
\hline tojos [tojos] & - & - & + & - & - & - & + \\
\hline $\begin{array}{l}\text { tubles } \\
\text { [tubləs] }\end{array}$ & - & - & + & - & + & - & - \\
\hline
\end{tabular}

Berikut contoh pemakaian leksem tersebut dalam kalimat.

(1) Asep ngagebugan (gebug) kasur make gagang kai ngarah beresih.

'Asep memukuli kasur menggunakan batang kayu supaya bersih.'

(2) Ida nojos (tojos) balon nu koneng nepi ka bitu.

'Ida menusuk balon yang kuning sampai meletus'.

(3) Kaca jandela peupeus dibalegog (baledog) ku nu gelo.

'Kaca jendela pecah dilempar batu oleh orang gila.'
Tabel 2

Aktivitas tangan menyakiti badan tanpa menggunakan alat

\begin{tabular}{|c|c|c|c|c|c|c|c|}
\hline \multirow[b]{3}{*}{ Leksem } & \multicolumn{7}{|c|}{ Komponen Makna } \\
\hline & \multicolumn{3}{|c|}{$\begin{array}{l}\text { Anggota } \\
\text { tubuh }\end{array}$} & \multicolumn{4}{|c|}{$\begin{array}{c}\text { Posisi } \\
\text { telapak } \\
\text { tangan }\end{array}$} \\
\hline & 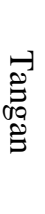 & 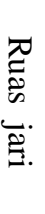 & $\overleftrightarrow{\mathrm{\Xi}}$ & & 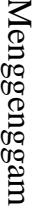 & के & \\
\hline beubeut [böböt] & + & - & - & - & - & + & - \\
\hline cakar [cakar] & - & - & - & + & - & - & + \\
\hline koét [kowet] & - & - & - & + & - & - & + \\
\hline ciwit [ciwit] & - & - & + & - & - & - & + \\
\hline $\operatorname{coco}[\operatorname{coco}]$ & - & - & - & + & - & - & + \\
\hline pencét [pəncet] & - & - & + & - & - & - & + \\
\hline perekpek [parəkpek] & + & - & - & - & + & + & - \\
\hline peureup [pöröp] & + & - & - & - & + & - & - \\
\hline talikung [talikun] & + & - & - & - & - & + & - \\
\hline tinggang [tingay] & + & - & - & - & + & & - \\
\hline
\end{tabular}

Berikut contoh pemakaian leksem tersebut dalam kalimat.

(4) Pipi orok teh beureum kacakar (cakar) kukuna sorangan.

'Pipi si bayi merah tercakar kukunya sendiri.'

(5) Ulah dipencet jarawatna bisi getihan.

'Jerawatnya jangan dipencet, nanti berdarah.'

\section{Aktivitas Tangan Menyakiti Kepala dan Bagiannya}

Aktivitas tangan menyakiti kepala dan bagiannya dalam bahasa Sunda ditemukan 17 leksem yang terdiri atas 2 leksem aktivitas menggunakan alat dan 15 leksem aktivitas tanpa menggunakan alat.

Leksem aktivitas tangan "menyakiti" kepala dan bagiannya dengan menggunakan alat adalah ketrok [kətrok], dan tarok [tarok]. Leksem aktivitas tangan "menyakiti" kepala dan bagiannya tanpa menggunakan alat adalah cabok [cabok], gampleng 
[gampləy], gaplok [gaplok], tampiling [tampilin], degung [dəguy], jembél [jəmbel], jenggut [jəygut], jiwel [jiwəl], jiwir [jiwir], jotos [jotos], keplak [kəplak], kerewes [kərəwəs], ketrak

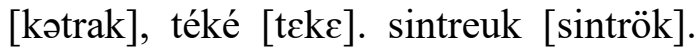
Berikut ini penjelasan leksem aktivitas tangan menyakiti kepala dan bagiannya. Penjelasan leksem aktivitas tangan menyakiti kepala dan bagiannya dapat dilihat pada tabel-tabel berikut.

Tabel 3

Aktivitas tangan menyakiti kepala dan bagiannya menggunakan alat

\begin{tabular}{|c|c|c|c|c|c|c|c|}
\hline \multirow[b]{3}{*}{ Leksem } & \multicolumn{7}{|c|}{ Komponen Makna } \\
\hline & \multicolumn{4}{|c|}{ Alat } & \multicolumn{3}{|c|}{$\begin{array}{c}\text { Posisi } \\
\text { telapak } \\
\text { tangan }\end{array}$} \\
\hline & 䒿 & $\begin{array}{l}\square \\
\stackrel{\Xi}{\Xi}\end{array}$ & 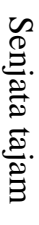 & 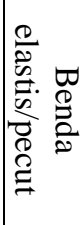 & 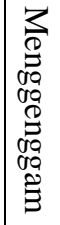 & 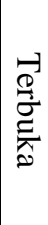 & $\underset{\mathrm{g}}{\stackrel{\Xi}{ٍ}}$ \\
\hline ketrok [kətrok] & - & + & - & - & + & - & - \\
\hline tarok [tarok] & - & - & + & - & + & - & - \\
\hline
\end{tabular}

Berikut contoh pemakaian leksem tersebut dalam kalimat.

(6) Sirah Amir diketrok batu nepi ga baloboran getih.

'Kepala Amir dipukul batu sampai berdarah banyak.'

Tabel 4

Aktivitas tangan menyakiti kepala dan bagiannya tanpa menggunakan alat

\begin{tabular}{|c|c|c|c|c|c|c|c|}
\hline \multirow[b]{3}{*}{ Leksem } & \multicolumn{7}{|c|}{ Komponen Makna } \\
\hline & \multicolumn{4}{|c|}{$\begin{array}{l}\text { Anggota } \\
\text { tubuh }\end{array}$} & \multicolumn{3}{|c|}{$\begin{array}{c}\text { Posisi } \\
\text { telapak } \\
\text { tangan }\end{array}$} \\
\hline & $\begin{array}{c}\stackrel{1}{0} \\
00 \\
\vdots \\
0\end{array}$ & 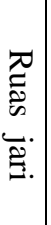 & ڤ્छ. & 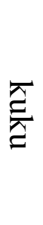 & 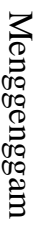 & $\begin{array}{l}\vec{Q} \\
\stackrel{\theta}{\sigma} \\
\stackrel{大}{\sigma}\end{array}$ & 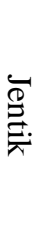 \\
\hline cabok [cabok] & + & - & - & - & - & + & - \\
\hline gampleng [gampləy] & + & - & - & - & - & + & - \\
\hline gaplok [gaplok] & + & - & - & - & - & + & - \\
\hline
\end{tabular}

\begin{tabular}{|c|c|c|c|c|c|c|c|}
\hline tampiling [tampilin] & + & - & - & - & - & + & - \\
\hline degung [dəguy] & - & - & + & - & - & - & + \\
\hline jembél [jəmbcl] & - & - & + & - & - & - & + \\
\hline jenggut [jəygut] & + & & + & - & + & & + \\
\hline jiwel [jiwəl] & - & - & + & - & - & - & + \\
\hline jiwir [jiwir] & - & - & + & - & - & - & + \\
\hline jotos [jotos] & + & - & - & - & + & - & - \\
\hline keplak [kəplak] & - & + & - & - & + & - & - \\
\hline kerewes [kərəwəs] & - & - & - & + & - & + & - \\
\hline ketrak [kətrak] & - & + & - & - & + & + & - \\
\hline téké [tcke] & - & + & - & - & + & - & - \\
\hline sintreuk [sintrök] & - & - & + & - & - & - & + \\
\hline
\end{tabular}

Berikut contoh pemakaian leksem tersebut dalam kalimat.

(7) Abdi janten ambek sabab anjeuna ngadegungkeun (degung) mastaka. 'Saya jadi marah karena dia menoyor kepala.'

(8) Buukna dijenggut (jenggut) nepi ka murudul.

'Rambutnya dijambak sampai rontok.'

\section{Aktivitas Tangan Menyakiti leher}

Aktivitas tangan menyakiti leher dalam bahasa Sunda ditemukan 3 leksem yang terdiri atas 1 leksem aktivitas menggunakan alat dan 2 leksem aktivitas tanpa menggunakan alat.

Leksem aktivitas tangan "menyakiti" leher dengan menggunakan alat adalah gorok [gorok]. Leksem aktivitas tangan "menyakiti" leher tanpa menggunakan alat adalah cekék [cəkck] dan tekuk [təkuk]. Berikut ini penjelasan leksem aktivitas tangan menyakiti leher. Penjelasan leksem aktivitas tangan menyakiti leher dapat dilihat pada tabeltabel berikut. 
Tabel 5

Aktivitas tangan menyakiti leher menggunakan alat

\begin{tabular}{|c|c|c|c|c|c|c|c|}
\hline \multirow[b]{3}{*}{ Leksem } & \multicolumn{7}{|c|}{ Komponen Makna } \\
\hline & \multicolumn{4}{|c|}{ Alat } & \multicolumn{3}{|c|}{$\begin{array}{c}\text { Posisi } \\
\text { telapak } \\
\text { tangan }\end{array}$} \\
\hline & 胥 & $\begin{array}{l}\square \\
\stackrel{\Xi}{\Xi} \\
\end{array}$ & 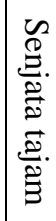 & 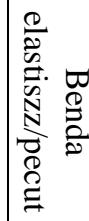 & 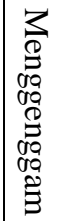 & ن & \\
\hline gorok [gorok] & - & - & + & - & + & - & \\
\hline
\end{tabular}

Berikut contoh pemakaian leksem tersebut dalam kalimat.

(9) Beuheung hayam digorok (gorok) make peso seukeut.

'Leher ayam disembelih menggunakan pisau tajam.'

Tabel 6

Aktivitas tangan menyakiti leher tanpa menggunakan alat

\begin{tabular}{|c|c|c|c|c|c|c|c|}
\hline \multirow[b]{3}{*}{ Leksem } & \multicolumn{7}{|c|}{ Komponen Makna } \\
\hline & \multicolumn{4}{|c|}{ Anggota tubuh } & \multicolumn{3}{|c|}{$\begin{array}{l}\text { Posisi } \\
\text { telapak } \\
\text { tangan }\end{array}$} \\
\hline & 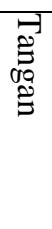 & 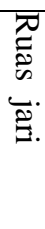 & 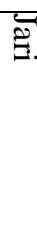 & $\overline{\bar{L}_{\mathrm{C}}}$ & \begin{tabular}{|c|}
3 \\
9 \\
00 \\
00 \\
00 \\
0 \\
0 \\
00 \\
00 \\
0 \\
$\Xi$ \\
\end{tabular} & $\begin{array}{l}\vec{Q} \\
\vec{Q} \\
\vec{E} \\
\vec{E}\end{array}$ & \\
\hline cekék [cək\&k] & + & - & + & - & + & - & + \\
\hline Tekuk [təkuk] & + & - & - & - & + & - & \\
\hline
\end{tabular}

(10) Malingna nyekek (cekek) korban ngarah teu ngalawan.

Si maling mencekik leher korban agar tidak melawan.

\section{Fungsi Semantis Medan Makna Aktivitas Tangan "Menyakiti" dalam Bahasa Sunda}

Fungsi semantis adalah fungsi yang berkaitan dengan makna satuan bahasa. Deskripsi fungsi semantis dalam verba aktivitas tangan "menyakiti" dalam bahasa Sunda adalah sebagai berikut.
Fungsi semantis aktivitas tangan menyakiti badan dengan menggunakan alat

\begin{tabular}{|c|c|}
\hline Leksem & $\begin{array}{l}\text { Makna Leksikal } \\
\text { Fungsi Semantis }\end{array}$ \\
\hline $\begin{array}{l}\text { babuk [babuk] } \\
\text { gebug [gəbug] } \\
\text { peupeuh } \\
\text { [pöpöh] } \\
\text { teunggeul } \\
\text { [töngöl] }\end{array}$ & $\begin{array}{l}\text { memukul } \\
\text { menyakiti bagian badan } \\
\text { seseorang dengan telapak } \\
\text { tangan atau alat, seperti kayu }\end{array}$ \\
\hline $\begin{array}{l}\text { bacok }[\mathrm{bacok}] \\
\text { kadék [kadck] } \\
\text { sabet }[\mathrm{sabət}]\end{array}$ & $\begin{array}{l}\text { membacok } \\
\text { membacok/menetak } \\
\text { menyabet } \\
\text { melukai bagian badan } \\
\text { menggunakan senjata tajam, } \\
\text { seperti golok dan } \\
\text { menimbulkan luka terbuka } \\
\text { serta mengeluarkan darah }\end{array}$ \\
\hline $\begin{array}{l}\text { baledog } \\
\text { [baledog] } \\
\text { paréngpéng } \\
\text { [parcypen] }\end{array}$ & $\begin{array}{l}\text { melempar/menimpuk } \\
\text { melempari bagian badan } \\
\text { menggunakan batu dan } \\
\text { antara pelaku dan sasaran } \\
\text { memiliki jarak. }\end{array}$ \\
\hline $\begin{array}{l}\text { ceprét [cəpret] } \\
\text { pecut }[\text { pəcut] }\end{array}$ & $\begin{array}{l}\text { mencambuk } \\
\text { Mencambuk bagian badan } \\
\text { menggunakan pecut atau } \\
\text { cambuk, biasanya punggung } \\
\text { dan antara pelaku dan } \\
\text { sasaran memiliki jarak. }\end{array}$ \\
\hline jepret [jopret] & $\begin{array}{l}\text { menjepret } \\
\text { Menyakiti bagian badan } \\
\text { menggunakan karet atau } \\
\text { benda elastis yang } \\
\text { diregangkan oleh ibu jari } \\
\text { dan telunjuk dan antara } \\
\text { pelaku dan sasaran memiliki } \\
\text { jarak. }\end{array}$ \\
\hline $\begin{array}{l}\text { tojos [tojos] } \\
\text { tubles [tubləs] }\end{array}$ & $\begin{array}{l}\text { menusuk } \\
\text { menikam } \\
\text { melukai dengan menusuk } \\
\text { bagian badan menggunakan } \\
\text { benda tajam, seperti } \\
\text { jarum/keris } \\
\text { menimbulkan luka }\end{array}$ \\
\hline
\end{tabular}

Fungsi semantis aktivitas tangan menyakiti badan tanpa menggunakan alat

\begin{tabular}{|c|c|}
\hline Leksem & $\begin{array}{l}\text { Makna Leksikal } \\
\text { Fungsi Semantis }\end{array}$ \\
\hline $\begin{array}{l}\text { beubeut } \\
\text { [böböt] }\end{array}$ & $\begin{array}{l}\text { membanting } \\
\text { menjatuhkan seseorang ke } \\
\text { permukaan yang keras/tanah }\end{array}$ \\
\hline
\end{tabular}




\begin{tabular}{|c|c|}
\hline $\begin{array}{l}\text { cakar [cakar] } \\
\text { koét [kowet] }\end{array}$ & $\begin{array}{l}\text { mencakar } \\
\text { mencakar bagian badan } \\
\text { menggunakan kuku }\end{array}$ \\
\hline $\begin{array}{l}\text { ciwit }[\text { ciwit }] \\
\text { coco }[\text { coco] }\end{array}$ & $\begin{array}{l}\text { mencubit } \\
\text { mencubit kecil } \\
\text { menjepit sedikit bagian } \\
\text { badan menggunakan ujung } \\
\text { ibu jari dan telunjuk (untuk } \\
\text { coco bisa berarti menggigit } \\
\text { yg dilakukan oleh binatang, } \\
\text { seperti nyamuk dan semut) }\end{array}$ \\
\hline $\begin{array}{l}\text { pencét } \\
\text { [pəncet] }\end{array}$ & $\begin{array}{l}\text { memencet } \\
\text { memijit/menekan dengan } \\
\text { keras bagian badan dan rasa } \\
\text { sakit yang ditimbulkan } \\
\text { tergantung pada kekuatan } \\
\text { pelaku dalam menekan }\end{array}$ \\
\hline $\begin{array}{l}\text { perekpek } \\
\text { [parəkpek] }\end{array}$ & $\begin{array}{l}\text { memukul bertubi-tubi } \\
\text { memukul bagian badan } \\
\text { beberapa kali, bisa dilakukan } \\
\text { oleh satu orang atau lebih }\end{array}$ \\
\hline $\begin{array}{l}\text { peureup } \\
\text { [pöröp] }\end{array}$ & $\begin{array}{llr}\text { mengepal } & & \\
\text { memukul } & \text { bagian } & \text { badan } \\
\text { dengan } & \text { tangan } & \text { yang } \\
\text { dikepalkan } & & \\
\end{array}$ \\
\hline $\begin{array}{l}\text { talikung } \\
\text { [talikun] }\end{array}$ & $\begin{array}{l}\text { memelintir } \\
\text { memelintir lengan sasaran } \\
\text { ke arah punggung sampai } \\
\text { tidak bisa bergerak }\end{array}$ \\
\hline $\begin{array}{l}\text { tinggang } \\
\text { [tingan] }\end{array}$ & $\begin{array}{l}\text { memukul } \\
\text { memukul bagian badan } \\
\text { (biasanya punggung) bisa } \\
\text { menggunakan tangan atau } \\
\text { alat keras, seperti kayu }\end{array}$ \\
\hline
\end{tabular}

Fungsi semantis aktivitas tangan menyakiti kepala dan bagiannya menggunakan alat

\begin{tabular}{llr}
\hline Leksem & Makna Leksikal & \\
\hline ketrok [kətrok] & memukul & \\
& $\begin{array}{l}\text { memukul kepala } \\
\text { menggunakan batu atau } \\
\text { benda keras }\end{array}$ & \\
\hline tarok [tarok] & memukul & \\
& melukai daerah kepala \\
& (biasanya & jidat) \\
& menggunakan senjata tajam \\
\hline
\end{tabular}

Fungsi semantis aktivitas tangan menyakiti kepala dan bagiannya tanpa menggunakan alat

\begin{tabular}{ll}
\hline Leksem & Makna Leksikal \\
\hline cabok $[\mathrm{cabok}]$ & menempeleng/ \\
gampleng & menampar \\
\hline
\end{tabular}

\begin{tabular}{|c|c|}
\hline $\begin{array}{l}\text { [gampləy] } \\
\text { gaplok } \\
\text { [gaplok] } \\
\text { tampiling } \\
\text { [tampilin] }\end{array}$ & $\begin{array}{l}\text { menampar } \quad \text { kepala } \\
\text { (pipi/pelipis) menggunakan } \\
\text { telapak tangan }\end{array}$ \\
\hline $\begin{array}{l}\text { degung } \\
\text { [dəgun] }\end{array}$ & $\begin{array}{l}\text { menoyor } \\
\text { menoyor kepala } \\
\text { menggunakan ujung jari } \\
\text { sampai kepala sasaran } \\
\text { terdorong }\end{array}$ \\
\hline $\begin{array}{l}\text { jembél } \\
\text { [jəmbel] }\end{array}$ & $\begin{array}{l}\text { mencubit } \\
\text { mencubit pipi dengan ibu } \\
\text { jari dan telunjuk, rasa sakit } \\
\text { yang timbul tergantung pada } \\
\text { seberapa banyak daging } \\
\text { yang tercubit dan tekanan } \\
\text { kedua jari tersebut }\end{array}$ \\
\hline $\begin{array}{l}\text { jenggut } \\
\text { [jəygut] }\end{array}$ & $\begin{array}{l}\text { menjambak } \\
\text { menarik rambut secara } \\
\text { kencang dan membuat } \\
\text { kepala sasaran terhentak } \\
\text { (rambut tercabut/rontok) }\end{array}$ \\
\hline $\begin{array}{l}\text { jiwel [jiwəl] } \\
\text { jiwir [jiwir] }\end{array}$ & $\begin{array}{l}\text { menjewer } \\
\text { menjewer telinga dan } \\
\text { menariknya, menimbulkan } \\
\text { rasa sakit dan panas, serta } \\
\text { telinga menjadi merah }\end{array}$ \\
\hline jotos [jotos] & $\begin{array}{l}\text { menonjok/ } \\
\text { menjotos } \\
\text { menonjok kepala denga } \\
\text { tangan dikepalkan }\end{array}$ \\
\hline $\begin{array}{l}\text { keplak } \\
\text { [kəplak] }\end{array}$ & $\begin{array}{l}\text { telapak tangan } \\
\text { memukul kepala }\end{array}$ \\
\hline $\begin{array}{l}\text { kerewes } \\
\text { [kərəwəs] }\end{array}$ & $\begin{array}{l}\text { mencakar } \\
\text { mencakar muka }\end{array}$ \\
\hline $\begin{array}{l}\text { ketrak }[\mathrm{k} ə t r a k] \\
\text { téké }[\mathrm{t} \varepsilon \mathrm{k} \varepsilon]\end{array}$ & $\begin{array}{l}\text { Memukul } \\
\text { memukul batok kepa } \\
\text { dengan ruas jari }\end{array}$ \\
\hline $\begin{array}{l}\text { sintreuk } \\
\text { [sintrök] }\end{array}$ & $\begin{array}{l}\text { Menyentil/menjentik } \\
\text { menyentil telinga dengan ibu } \\
\text { jari dan telunjuk }\end{array}$ \\
\hline
\end{tabular}

Fungsi semantis aktivitas tangan menyakiti leher menggunakan alat

\begin{tabular}{ll}
\hline Leksem & Makna Leksikal \\
\hline gorok [gorok] & menggorok/ \\
& menyembelih \\
& memotong leher dengan \\
& senjata tajam, seperti golok \\
\hline
\end{tabular}


Fungsi semantis aktivitas tangan menyakiti leher menggunakan alat

\begin{tabular}{ll}
\hline Leksem & Makna Leksikal \\
\hline cekék [cəkøk] & mencekik \\
& mencekik leher dengan \\
& $\begin{array}{l}\text { melingkarkan jemari tangan } \\
\text { sehingga sasaran tidak bisa } \\
\text { bernafas }\end{array}$ \\
\hline tekuk [təkuk] & $\begin{array}{l}\text { menekuk } \\
\text { menekukkan leher (bisa } \\
\text { sampai patah) }\end{array}$ \\
\hline
\end{tabular}

\section{PENUTUP}

Hasil analisis data menunjukkan bahwa aktivitas tangan "menyakiti" dalam bahasa Sunda yang dibagi ke dalam dua kelompok, yakni berdasarkan komponen makna generik dan alat yang digunakan. Komponen makna dibagi lagi menjadi tiga subkelompok, yaitu aktivitas tangan menyakiti badan, aktivitas menyakiti kepala dan bagiannya, dan aktivitas menyakiti leher. Aktivitas tangan menyakiti badan dalam bahasa Sunda sebanyak 24 leksem terdiri atas 14 leksem aktivitas menggunakan alat, yaitu bacok [bacok], baledog [baledog], ceprét [copret], gebug [gəbug], jepret [jəpret], kadék [kadek], paléngpéng [palcypen], pecut [pəcut], peupeuh [pöpöh], sabet [sabət], teunggeul [töngöl], tojos [tojos], dan tubles [tubləs], sementara 10 leksem aktivitas menyakiti badan tanpa menggunakan alat, yaitu beubeut [böböt], cakar [cakar], ciwit [ciwit], coco [coco], jotos [jotos], koét [kowet], pencét [pəncet], perekpek [parəkpek], peureup [pöröp], talikung [talikuy], tinggang [tingan], dan tonjok [tonjok]. Kemudian, aktivitas menyakiti kepala dan bagiannya sebanyak 17 leksem terdiri atas 2 leksem aktivitas menyakiti kepala dan bagiannya menggunakan alat, yaitu ketrok [kətrok] dan tarok [tarok] dan 15 leksem aktivitas tangan "menyakiti" kepala dan bagiannya tanpa menggunakan alat adalah cabok [cabok], gampleng [gampləy], gaplok [gaplok], tampiling [tampilin], degung [dəguy], jembél [jəmbel], jenggut [jəngut], jiwel [jiwal], jiwir [jiwir], jotos [jotos], keplak [kəplak], kerewes [kərəwəs], ketrak [kətrak], téké [tcke], dan sintreuk [sintrök]. Adapun leksem aktivitas tangan menyakiti leher terdiri atas 1 leksem aktivitas menyakiti leher menggunakan alat, yaitu gorok [gorok] dan 2 leksem aktivitas menyakiti leher tanpa menggunakan alat, yaitu cekék [cəkck] dan tekuk [təkuk]. Makna leksikal aktivitas menyakiti pada umumnya adalah memukul. Akan tetapi, fungsi semantis leksem-leksem tersebut berbeda berdasarkan komponen makna yang dimilikinya. Fungsi-fungsi semantis lain di antaranya adalah mencubit, menjewer, menempeleng, menoyor, mencakar, dan membacok.

Penelitian ini merupakan penelitian awal yang masih perlu dikembangkan dan diperdalam agar leksem-leksem aktivitas tangan "menyakiti" lainnya yang terlewat dapat terinventarisasi.

\section{DAFTAR PUSTAKA}

Aminuddin. (1998). Semantik: Pengantar Studi Tentang Makna. Bandung: Sinar Baru.

Chaer, A. (2013). Pengantar Semantik Bahasa Indonesia. Jakarta: Rineka Cipta.

Darheni, N. (2010). Leksikon Aktivitas Mata dalam Toponim di Jawa Barat: Kajian Etnosemantik. Linguistik Indonesia, 1(Februari 2010), 55-67.

Darlisanto, M. (2014). Medan Makna Verba Memukul dalam Bahasa Melayu Sambas. Jurnal Pendidikan Dan Pembelajaran, 3 Nomor 9(September 2014), 119. 
Herdiana, I. (2011, November 23). Pemakai bahasa Sunda tinggal $43 \%$. p. Retrieved from https://news.okezone.com/read/2 011/11/23/447/533367/pemakaibahasa-sunda-tinggal-43

Hutasuhut, A. (2008). Medan Makna Aktivitas Tangan dalam Bahasa Mandailing (Universitas Sumatera Utara). Retrieved from http://repository.usu.ac.id/bitstrea $\mathrm{m} / \mathrm{handle} / 123456789 / 5696 / 08 \mathrm{E} 0$ 0702.pdf;jsessionid=62AF0CB2 AE22F6BFC56AE12B4B70F3B A? sequence $=1$

Kreidler, C. W. (1998). Introducing English Semantics (1st ed.). London: Routledge.

Kridalaksana, H. (2008). Kamus Linguistik (4th ed.). Jakarta: Gramedia Pustaka Utama.
Malay, N. M. (2017). . Peran Semantis Verba dalam Klausa Transitif pada Teks Cerita Bahasa Sabu yang Berjudul Ana Kedakke Nga Hika(Anak katak dan Murai), Ammu Helapa( Rumah Sepatu), Rena Maddi(Hengiu Manu) Nga Madda (Si hitam=seekor ayam dan Musang) dan Ma Wadu Riwu (Universitas Nusa Cendana). Retrieved from http://infontt.com/2017/10/30/per an-semantis-verba-dalam-klausatransitif-teks-cerita-bahasa-sabu/

Nida, E. (1975). Componential Analysis of Meaning. Netherland: The Hague.

Saeed, J. I. (2016). Semantics (4th ed.). United Kingdom: Blackwell Publisher.

Soedjito. (1990). Kosa Kata Bahasa Indonesiua. Jakarta: PT Gramedia.

Sugiyono. (2012). Metode Penelitian Pendidikan: Pendekatan Kuantitatif, Kualitatif, dan R\&amp;D. Bandung: Alfabeta. 